\title{
Telecommunications Policy Models and Their Application -A Case Study of Korea-
}

\author{
KIM, EUN-JU* \\ Assistant Professor, Internationsl Institute for Telecommunications Scbool of Social Science \\ The City University, London
}

\begin{abstract}
Many have looked at various aspects of telecommunications issues particularly influenced by technological innovation and merger. However, there were a very few who overviewed and classified the different spectrums of telecommunications policy in the rapidly changing and complex telecommunications environment. Thus, it aims at examining the different types of telecommunications policy worldwide and applying them to Korea, through which the persons or countries concerned can further research, facilitate their telecommunications development and consequently spur the socio-economic welfare.
\end{abstract}

\section{Introduction}

In accordance with technological innovation and merger, there has been in recent growing recognition regarding the importance of telecommunications and its impacts on the overall socio-economic growth. Moreover, the telecommunications sector, which had been typically treated as a mere technical domain, is being placed on a high priority as a strategic area for the forthcoming 21st century.

That is why several advanced countries including the U.S.A., Japan, the EU, and even the Republic of Korea (hereinafter 'Korea') cooperate, if not compete, to build information superhighway based on national information infrastructure

"She, who is a senior research fellow of the KISDI and special advisor for the Ministry of Communications, the Republic of Korea, will be an assistant professor at the City University, London, from January 1, 1995.

The Korean Journal of Policy Studies Vol. 9 (1994), 67 90 
(NII), regional one (e.g., Asia-Pacific Information Infrastructure and TransEuropean Network), and eventually global one (Global Information Infrastructure) through utilizing not only national industries but also international arenas such as the Asia-Pacific Economic Cooperation (APEC), the European Union (EU) and the International Telecommunication Union (ITU).

Although a number of researches have looked at various aspects of telecommunications issues, there were not many to overview and classify the different spectrums of telecommunications policy in the rapidly changing and complex telecommunications environment. Nonetheless, many argue that it is not the mere technology per se but the policy which determines the national and international telecommunications development (E.J.Kim, 1993a).

In this context, this article first intends to examine the different types of telecommunications policy, and then apply them to Korea. Its main purpose is in part to suggest the persons or countries concerned a policy model(s), through which they can further research, facilitate their telecommunications development, and consequently spur the overall socio-economic growth.

To this end, it will first look at evolving concepts or issues of telecommunications. Second, four different types of telecommunications policy depending upon the time-period and/or social structure will be examined. Third, the different types of policies will be applied to Korea as a case study. Last but the least, the effects of telecommunications policy implemented in Korea will be analyzed in order for countries, the developing countries inter alia, to be lessened from them.

\section{Changing Concepts of Telecommunications}

\section{Technological Concept}

The concept of telecommunications defined in the International Telecommunication Convention of the ITU is "Any transmission, emission or reception of signs, writing, images and sounds or intelligence of any nature, by wire, radio, optical or other electromagnetic systems" (ITU, 1992).

Telecommunications, here, tends to be technology per se, of which transmission may take one of the following three forms: 1) "electrical signals along a conductor; 2) electromagnetic radiation; or 3) light signals passing along an optical fiber" (D.Longley \& M.Shain, 1989).

However, the term telecommunications technology is often identified or confused with information technology mainly due to the convergence of telecommunications, computer and even broadcasting in the era of broadband communications. 


\section{Economic Concept}

Rapid innovation of the telecommunications technology leading to the emergence of various new services has impacted on various socio-economic aspects of the national and international telecommunications community (N.D.Karunarantne, 1983).

Many have already approved that telecommunications now becomes a prime impetus not only for supporting other economic infrastructures but also for directly generating socio-economic development (R.Dholakia \& B.Harlam, 1994). It mainly stems from the growing size of telecommunications markets, which are structured by both telecommunications equipment and service industries.

Indeed, a recent study calculates the telecommunications-broadly, information-sector to account for $34 \%$ of the American GNP and $41 \%$ of the labor force. The European Commission also projects that by the year 2000 almost $60 \%$ of its jobs will depend on the telecommunications-related activities. In consequence, the advent of telecommunications economy, more broadly information economy, is being strengthened by the the merger of not only technologies but also industries in the fields of computers, telecommunications, and broadcasting.

Moreover, "the major advances in telecommunications are playing an even bigger role in shortening the economic distance between countries, promoting the globalization of markets with various participants and greatly stimulating the scope for international trade" (GATT, 1988). In return, "telecommunications is now inextricably interwoven with other economic sectors, the broad industrial and trade policy, consequences of which should not be decided purely by administration engineers" (W.J. Drake, 1988).

That is why, today, more heated negotiations or discussions on telecommunications issues by economists, lawyers, policy-makers apart from the traditional engineers have ever been required at both bilateral, pluilateral and multilateral levels such as the Uruguay Round of the General Agreement on Tariffs and Trade (MOJ, 1994), the European Union (L. Garfinkel, 1994), and the ITU (E.J. Kim, 1993b).

\section{Policy Concept}

It is also important to note that technology per se is not deterministic. Rather, it is efficient management or implementation of the technology subject to the politico-economic characteristics of each nation-i.e., policy, that determines a nation's telecommunications competence.

In practice, technology itself is practicable and feasible to provide people with 
broadband-ISDN services such as 'Video-on-Demand', 'HDTV' etc. with a variety of choices due to the development of fiberoptical cables, satellites, and digital technologies at both national and international levels.

However, hardly can these high-tech services be available yet because of the existing national and international regulations and policies especially in certain countries like Japan, Korea, and even the U.S.A.. Here, it is important to note the policy and its implications.

Telecommunications policy has been traditionally regulated by the governments so that it has been regarded as stable. However, "an apparent phenomenon in the current global telecommunications is the movement towards deregulation, liberalization, or privatization, although the scope and degree differs depending on each country" (E.J. Kim, 1990).

\section{Different Types of Telecommunications Policy}

Telecommunications policies are very different as between different countries and reflect the political ideology of each country, the levels of economic development, the social attitudes and so on.

The ultimate goal of telecommunications policy would be socio-economic efficiency, which maximizes the telecommunications welfare of the people and facilitates the overall socio-economic growth.

However, there is not an or the accepted model applicable for every county to meet the ultimate policy objective. This section reviews the following four different types of telecommunications policy model:

1). regulated model;

2). mixture of regulated and liberalized model;

3). liberalized or deregulated model; and

4). re-regulated model.

These models can be, yet, evolved from the regulated model to re-regulated one over time, and combined and even overlapped between them subject to each country's circumstances.

\section{Regulated Model}

The rationales for regulation, that is the system of rules governing the market laid down by government, in any sector of the economy which would produce maximum social welfare have varied even over time.

Most of countries with a few exceptions like the U.S.A. had regulated the telecommunications infrastructures from the beginning. In practice, the governments (PTT) had played dual roles for regulation and operation of telecommuni- 
cations. Why?

In the early days, telecommunications had been regarded as a public good and hence assumed to be provided by the public body like the government.

Later or recently, the policy of regulation is envisaged as being necessary or inevitable in order to prevent undesirable practices in industries such as a natural monopoly and to provide universal services at relatively low rates to customers.

Based on this belief, most countries through government authorities (e.g., PTTs) regulate telecommunications infrastructures and even directly run every aspect of the telecommunications networks, its associated services and facilities including terminal equipment.

In practice, considerations based on diversity, advanced technology, and contestability of market structure depending on the notion of ease of market entry are all less applicable to most developing countries and even to some developed countries.

\section{Mixture of Regulated and Liberalized Models}

Regardless the pros and cons of regulation and liberalization in theory, some countries can implement their policy in the middle or mixture of them due to their own political, economic, and social circumstances or on the way towards implementing full liberalization.

The combinations of mixture can vary in and differ from one country after another. Namely, some may regulate their telecommunications services while liberalizing telecommunications equipment.

The degree of both regulation and liberalization can also vary in telecommunications equipment as well as services of each country. For example, most countries still regulate basic-or traditional telephony-services, while liberalizing the value-added or enhanced services. Regarding the latter, moreover, some countries open more than others.

\section{Lberalized or Deregulated Model}

The concept of liberalization identifies a "transfer of markets from a system based on rules made by governments to one based on competition between private entities" (J. Hills, 1989). Its fundamental assumption is based on a view that in free market exchanges between individuals will lead to an efficient or optimal allocation of resources.

In other words, political interference with the process causes inefficiency to the extent that it directs productions away from that pattern of goods and services which would occur from the exchanges of individuals. 
Based on this belief, countries like the U.S.A. physically and virtually open the telecommunications networks, facilities, and services. They decide not to regulate-i.e., deregulate-them because "either such regulations cause inefficiency or such deregulation can be a positive force to stimulate competition" (CECUHR, 1981).

Then, why and how has liberalization emerged from traditionally monopolized telecommunications sector ? The most frequently cited reason was the need to realize the vast potential of technical change in telecommunications (E. Sciberras \& B.D. Payne, 1986).

However, "the technology itself does not create the pressure, rather innovation or the convergence of computer and telecommunications technologies has not only introduced new actors such as IBM into the traditional telecommunications market, but also allowed multinational companies to provide their own networks at low costs" (J. Hills, 1989).

Hence, it is kind of combination among technological, economic, and political incentives in order for the countries to liberalize their national and international telecommunications.

\section{Re-Regulated Model}

The concept of re-regulation implies to regulate the once liberalized market by the government or its affiliates again and/or even by the new regulations such as license, enforcement, and laws in order to protect the public from the abuses of heated competition among various private entities.

It can be derived from the trend or fact that "the forces of liberalization have been too aggressive in pressing for rapid change; too quick to pass judgment on diverse national policies; and too intensive to legitimate sovereign rights and social objectives" (W.J. Drake, 1988).

Thus, some argue that unless safeguards are provided for adversely affected interest groups, liberalization or privatization itself could be well jeopardized. It can be well illustrated at setting up or using the regulatory bodies such as the OFTEL (the U.K.) and the FCC (the U.S.A.) as well as at enacting or revising such regulations as the Telecommunication Enforcement (Korea) and the new licenses for limited service providers (the U.K., Germany, Australia etc.).

\section{The Telecommunications Policy Model in Korea}

The concept of telecommunications in Korea like most other countries began in 1885, when telegraph was first introduced. Thereafter, her telecommunications policies have been evolving over time as illustrated in <Table 1$\rangle$. 
<Table 1> Telecommunications Development under the Politico-economic Regimes in Korea (1985 1994)

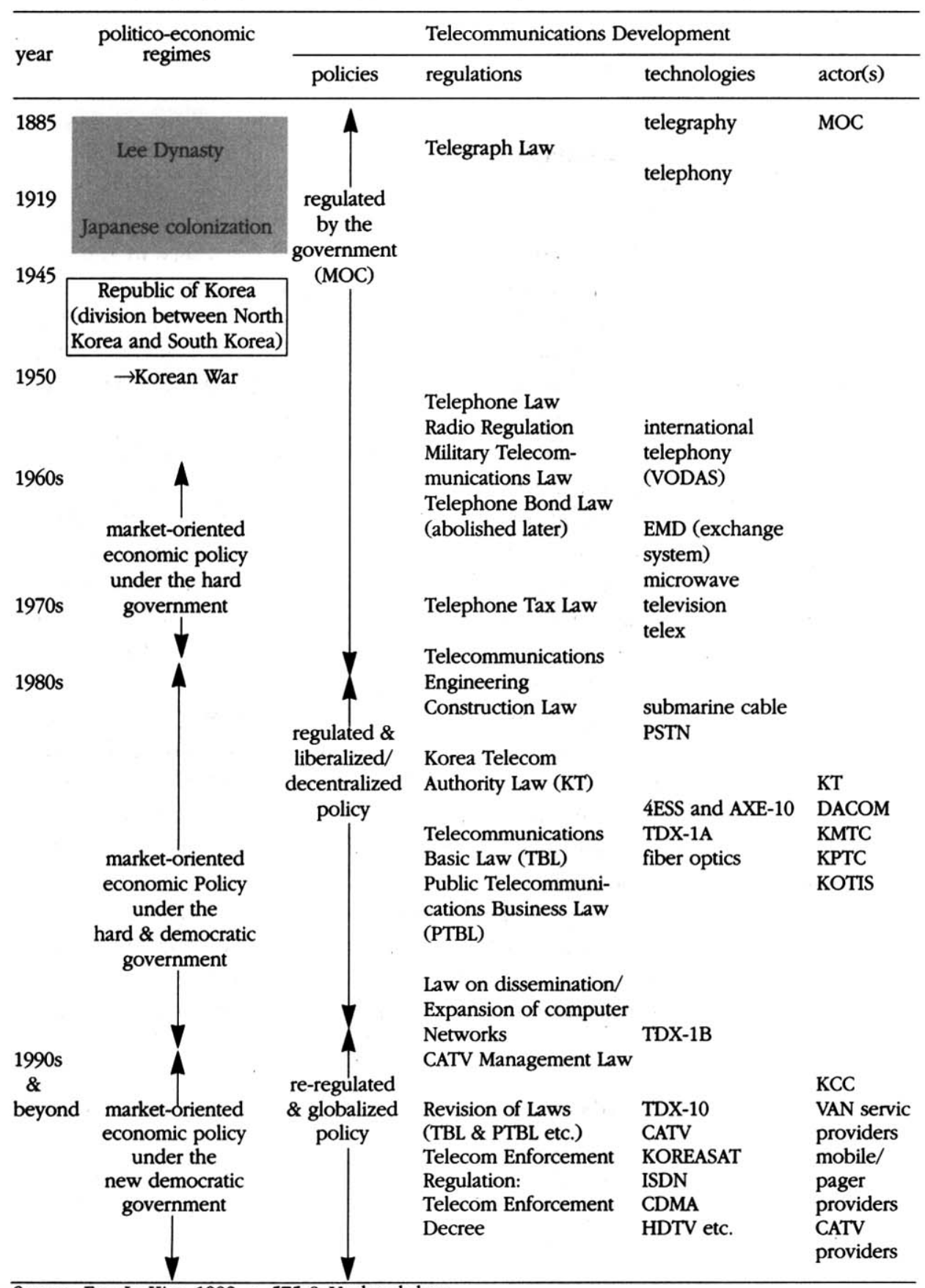


Mainly influenced by the changing political regimes, three different types of models can be largely applied to her telecommunications as follows:

1). until the late 1970s;

2). during the 1980s; and

3). the 1990 s and beyond.

\section{Until the Late 1970s: Regulated Model}

Korea underwent several crises such as the Japanese invasion (1919-1945) and the Korean War (1959-1953) before achieving a measure of stability in the mid1950s. By this time most of the country's telephone and telegraph systems had been destroyed, and their replacement was urgent. For example, Seoul (the capital) with a population of 2 million, had only 17,000 telephones (i.e., 0.0085 per a person) and its facilities were seriously overloaded (ITU, 1959,p.171). Heavy backlogs in demand for telephones continued until the late 1970s.

In this period, Korea like most other developing countries saw telecommunications as a source of fiscal revenue and essential for national security rather than as a basic infrastructural prerequisite for socio-economic development. It was therefore inevitable for the government either to run the telecommunications infrastructures directly or to entrust it to a state-run corporation with the legal protection of a monopoly so as to secure sufficient resources, and to give priority to government and key industries in the utilization of the limited resource of telecommunications equipment (E.J. Kim, 1992, pp. 573-574).

However, owing to the four consecutive Five-Year Economic Development Plans beginning in 1962, basic telecommunications like switching facilities increased from 120,000 lines in 1961 to 1.7 million in the end of 1970s. The pace of development was attributable in part to the hard government called "bureaucratic-authoritarian regimel) which reflected its superlative economic performance based on market-oriented policy or industrialization" (E.J.Kim, 1990).

Overall, unlike in the most developed countries, it was the government which first recognized telecommunications as part of the social overhead costs essential to national economic development and tightly regulated its sector. Thus, telecommunications policy in this period could be categorized as the typically regulated model.

\section{The Dramatic 1980s: Mixture Between Regulated and Liberalized Model}

The 1980s was a time when Korea faced challenges of economic and political transformation. There was increased pressure to introduce a greater role for democracy in politics as well as liberalized market-oriented principles in the eco- 
nomic sphere in order to achieve managerial efficiency. The centralizing government-dominated system gradually gave way to a decentralizing or deregulating policy which encouraged pubic participation during the 1980s.

In the field of telecommunications, the scope of such changes ranged from reforming the legal framework (see <Table 1>) to liberalizing terminal equipment and consequently foreign investment. In particular, restructuring of telecommunications infrastructures led to more actors such as Korea Telecom (KT), DACOM, and Korea Mobile Telecom (KMT) from the sole actor - i.e., the government (MOC).

The term liberalization in her telecommunication sector, yet, referred largely to the transfer of the role as an operator from the government (MOC) to common carriers (e.g., KT and DACOM) in the early 1980s. The government still owned the whole shares of KT and intervened in operating its infrastructures. It did not also allow these carriers to compete with each other over the same services: KT for basic voice services, DACOM for non-voice services (E.J. Kim, 1993a).

Thus, the primary policy in this period can be in character summed up as the mixture of regulated and liberalized model. Although the functions of making policies as well as operating facilities and services were separated between the government and common carriers, the government still regulated the carriers in terms of the scope of services, tariffs, foreign investments, etc..

\section{The 1990 s and Beyond: Re-Regulated Model}

In the beginning of 1990 s, "the Korean Government established the 7 th FiveYear Economic and Social Development Plan, which states its prime objectives as advancement to the level of industrialized countries and the reunification of the Korean peninsula. To meet these objectives, Korea centered by the Ministry of Trade, Industry, and Energy (MTIE) is in particular to pursue economic deregulation and further market-opening measures, and promote international economic cooperation" (MTIE, 1992).

In line with this macro politico-economic policy, the MOC decided restructuring of infrastructure on the basis of revising the Telecommunication Basic Law subject to the following three different service areas: 1 ). general communications services (e.g., traditional voice telephony services); 2). specific communications services (e. g., mobile car-phone and paging services); 3). value-added network services (J.E. Cheon, 1991). However, this distinction between or among the service areas becomes more and more blurred particularly at an international level, because of technological development and merger as well as industrial marriage between providers cross services (E.J. Kim and Y.O. Jin, 1993C).

It is also worth noting that the new civil Government, which took its power by 
public election in 1993, replaced the existing 7th Development Plan with the New Economic Development Plan. The latter considers telecommunications as a strategic area to realize the information society in the 21 st century.

To this end, the Government places high priorities on national technology development including "personal communications equipment, multi-media, the next generation of switching system (e.g., ATM), digital mobile communications system (e.g., CDMA), optical fiber transmission system for digital CATV and HDTV, ISDN terminal" (Korean Government, 1993, pp. 199-205) on the basis of the development of basic telecommunications facilities.

To meet various internal and external challenges, in particular, the government (MOC) introduced a step-by-step approach for liberalization with limited competitions at various levels except for local voice service which is still monopolized by KT.

At a first step, Korea Telecom (KT) for the first time began to compete with DACOM to provide international telephone services from 1991. In 1994, competitions were further introduced in the areas of value-added services with full participation of foreign investments and mobile communication services with limited foreign investments.

However, it is also worth noting that the Korea Communications Commission (KCC) - a watchdog body-was set up under the auspices of the MOC in 1992. A number of regulations including Telecommunication Enforcement Regulation and Decree were newly adopted or revised to monitor and regulate the new actors in the field of telecommunications (E.J. Kim, 1993a). Furthermore, more licenses were required and issued for the new-but, limited-service providers in the areas of mobile communications, cable TV (E.J. Kim, 1994), and so on in the 1990 s.

To sum up, the policy of this period can be in character regarded as the re-regulated model.

\section{Effects of the Telecommunications Policy in Korea}

Effects from implementing the policy can differ depending upon each period or model. It is also worth noting that although the degree of government intervention differed in line with the changing political regimes from the hard government until the 1980 s to more liberalized one in the 1990 s, the government has intervened and still intervenes various levels of telecommunications management in Korea. However, the major outputs from the step-by-step approach from the regulated policy to the re-regulated one over time are as follows. 


\section{Revisions of the Telecommunications Regulatory Regimes}

The evolution of telecommunications policies has progressed hand in had with its regulatory reforms. For instance, it was 1961 when Korea started to revise the telecommunications regulations which contained the telephone and telegraph laws enacted in the period of Japanese control. In particular, the the Telephone Bond Law was enacted in December 1961, in order to raise the amount of capital required for expanding and improving telecommunications facilities. This law was replaced by the Provisional Law on Public Telecommunications Facilities in December 1979, which was abrogated in January 1988 when the demands for basic telecommunications facilities were regarded to be satisfied (MOC, 1991, pp. 143-144).

The evolution of telecommunications policies, especially in the 1980s, has paralleled a set of regulatory reforms (see <Table $1>$ ). Such regulatory reforms reflected demands for decentralization of the politico-economic structure in a broad sense, and of telecommunications infrastructures in a narrow sense (Haggard, 1987, pp. 491-517). However, it is interesting to note that such reforms did not intend to exclude government regulation. For example, the Telecommunications Basic Law still gave the government (MOC) the authority to establish and enforce local content requirements, to deny import licenses, and to restrict public sector procurement of products containing a stipulated level of local content (Kuznets, 1985, pp. 44-66).

Furthermore, the Telecommunication Basic Law and the Public Telecommunications Business Law were revised subject to three different service areas in 1991, as above mentioned, to introduce competitive principles in the telecommunications sector. The major characteristics of each service area in the revised laws are as follows:

1) a monopoly will remain in local voice services;

2) competition will be incrementally introduced in international voice services as well as mobile communications services; and

3) early competition will be allowed in VAN services.

In particular, the Basic Law requires that the MOC request the network service providers including both general and specific service providers to furnish financial support for institutions and organizations conducting research and development (R\&D) in this sector. The Business Law can be summarized as a classification of the characteristics of services and their providers, of which conditions and procedures are all differently required for each service category (Choi, 1991). Also, the Law on R\&D of the Information Communications was enacted in 1991 to facilitate R\&D in the VAN service areas (Jeonjasibosa, 1992,p.93). 
In this context, it is questionable whether such a series of reforms tend to be reregulation rather the deregulation (or liberalization) in Korea. Apart from the theoretical rationals for the liberalization earlier examined, it is in practice necessary to note that government intervention-whether through regulations, policies, or $\mathrm{R} \& \mathrm{D}$ investments-seems to be the rule rather than the exception in the processes of liberalization (Arnold and Guy, 1986, p.32), given the experience of many countries. Thus, a crucial factor for successful implementation of any regulation is the harmonization between the process of revising regulations and the way of implementing them in the rapidly changing national and international telecommunications environment (E.J. Kim and Y.O. Jin, 1993c, pp. 235-238).

\section{Liberalization of Telecommunications Infrastructures}

Influenced by the overall politico-economic policies, telecommunications policies such as liberalization, decentralization and privatization have been intensified through restructuring of various infrastructures in accordance with on-going revisions of the relevant regulations in the 1990s.

In line with the revision of relevant regulations, the actors have been diversified from the sole actor - the MOC, which was used to be a both regulator and operator-to many, as seen in <Table 2>

It articulates that liberalization led to diversification of actors concerned. Here, one may raise a question whether the liberalization or decentralization would weaken the Government's status. This may be so, to some extent. However, the MOC still retains the dominant power over decision-making in the field of telecommunications due to her unique politico-economic atmosphere which can be in character 'government-centred corporatism rather than pluralism'2), on the one hand. On the other, as the actors are diversified with conflicting interests, so the MOC may play a role as an arbitrator among the actors.

Influenced by the liberalization, furthermore, the border between manufacturing and service industries is becoming blurred and working closely in various aspects of telecommunications. Indeed, the manufacturing companies-conglomerates, inter alia - have taken over these industries. To some extent, the liberalization has already allowed them not only to become the potentially large users but also to enter service markets as providers.

For example, large companies like SunKyong became the largest shareholder company of the Korea Mobile Telecom (KMT), whilst POSCO and KOLON became the first and second largest shareholders of the second mobile communications providers respectively. Moreover, the single consortium of the latter is also composed of the major four conglomerates, which manufacture switching system as well as participate in developing the the next generation of digital technology 
<Table 2> Liberalized Telecommunications Infrastructures

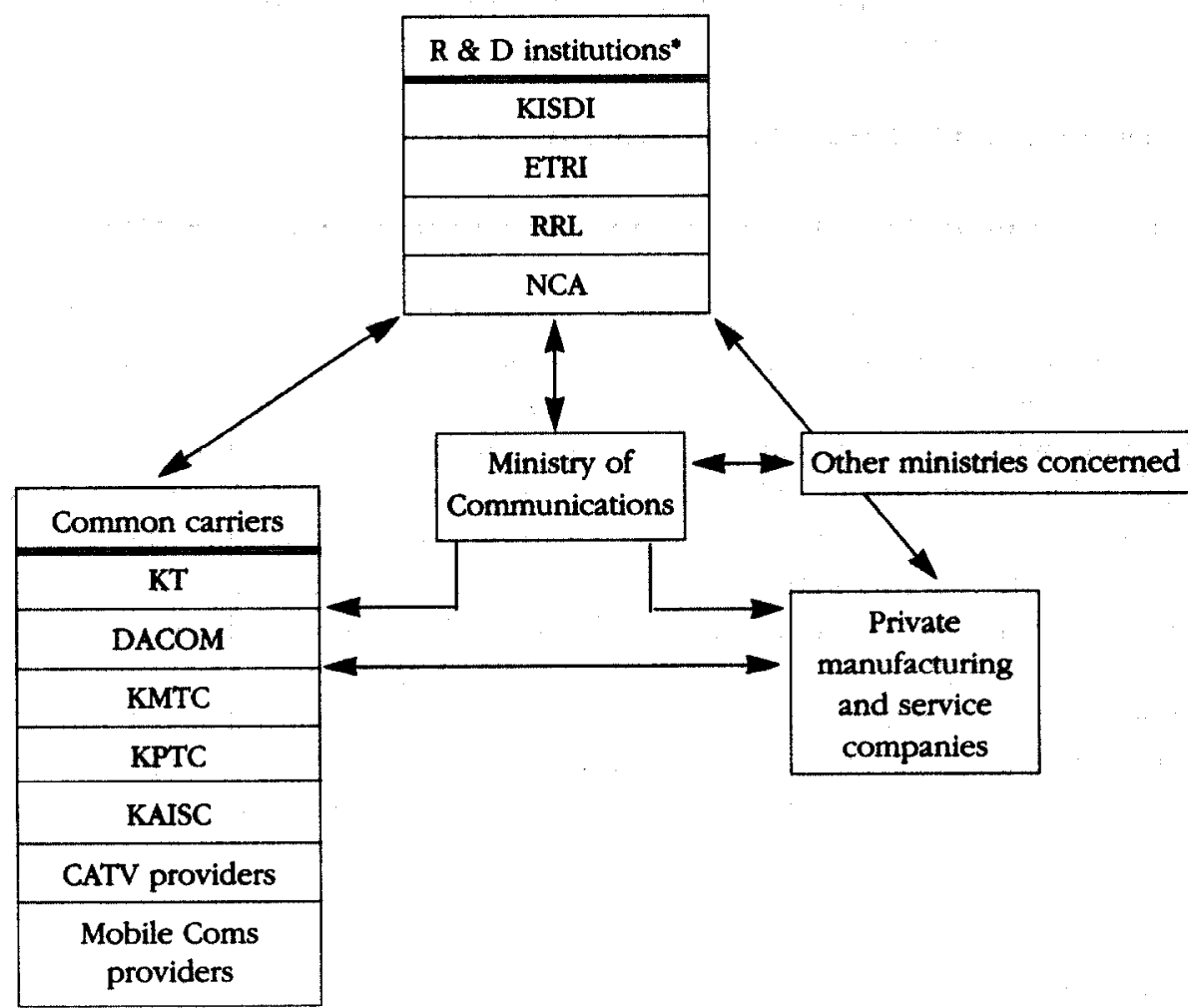

Note: KISDI (Korea Information Society Development Institute)

ETRI (Electronics \& Telecommunications Research Institute)

RRL (Radio Research Laboratory)

NCA (National Computerization Agency)

KMTC (Korea Mobile Telecom Co.)

KPTC (Korea Port Telecom Co.)

KAISC (Korea Airport Information Service Co.)

Source: E.J.Kim, 1993a \& updated

"Many of common carriers and companies have their own R \& D institute.

for mobile communications (e.g., CDMA).

It is also worth noting that a driving factor to facilitate the manufacturing capabilities of telecommunications in Korea would be the procurement power of the general service providers (e.g., KT). For instance, KT has been installing facilities at the rate of over one million telephone lines annually since 1980 , which at present led to reach about 20 million. This investment allowed KT to provide stable 
markets for local industries and to help them upgrade their product quality by implementing such measure as demands forecasting system and quality assurance system (E.J. Kim, 1994).

\section{Development of Telecommunications Facilities}

\section{Development of The Automatic Electronic Switching System: TDX- Series}

The basic telephone switching facilities developed from 120,000 lines in 1961 to about 20 millions in 1994, which ranks about tenth in the world, as seen in $<$ Figure 1>. As a result, Korea now has a higher teledensity than Ireland, Portugal and Spain, which are OECD and EU member countries (ITU, 1994. pp. 85-87).

This achivement mainly relies upon the TDX-series. The TDX-series is locally developed and manufactured automatic electronic switching system. The series, as seen in <Table 3>, was initiated from TDX-1A with a capability of about 10,000 lines in 1985. It has been overtaken by the TDX-1B, a more sophisticated version that is based on 32 bit processing. Moreover, the TDX-10 with a capacity of 100 , 000 lines began to replace not only the previous TDX system but also a variety of foreign switching systems such as M10CN (ITT-BTM), No.1A \& No.5ESS (AT\&T), and S1240 (BTM). In particular, this TDX-series, which is manufactured by domestic companies with heated competition, has been exported to about 30 countries between 1991 and 1993.

\section{Koreasat}

Korea will for the first time in her history launch two satellites called KOREASAT consisting of 12 channels for telecommunications and 3 channels for broadcasting in 1995 (H. Hwangbo, 1992). This project, which will cost about US $\$ 400$ million, is expected to encourage state-of-the-art technology of satellite, launch vehicle and control facilities, and terrestrial equipment in Korea.

In order to carry out the KOREASAT project, there were two steps of competition or bidding, where foreign companies could partake: The first was to select a consortium for manufacturing it in 1991. The second was for launching it in 1992. Here, one may argue whether Korea will fall into reliance upon foreign technologies and know-how. Based on technology transfer from the participating foreign companies, however, the main intention is that the second generation of KOREASAT plans to be localized. In addition, it is important to note that "although KT is in charge of its business providing services such as VSAT, the MOC will be still responsible for policies concerned to secure public interests." (B.H. Seo et.al., 1991)

It is also worth questioning the necessity or even commercial profitability of 


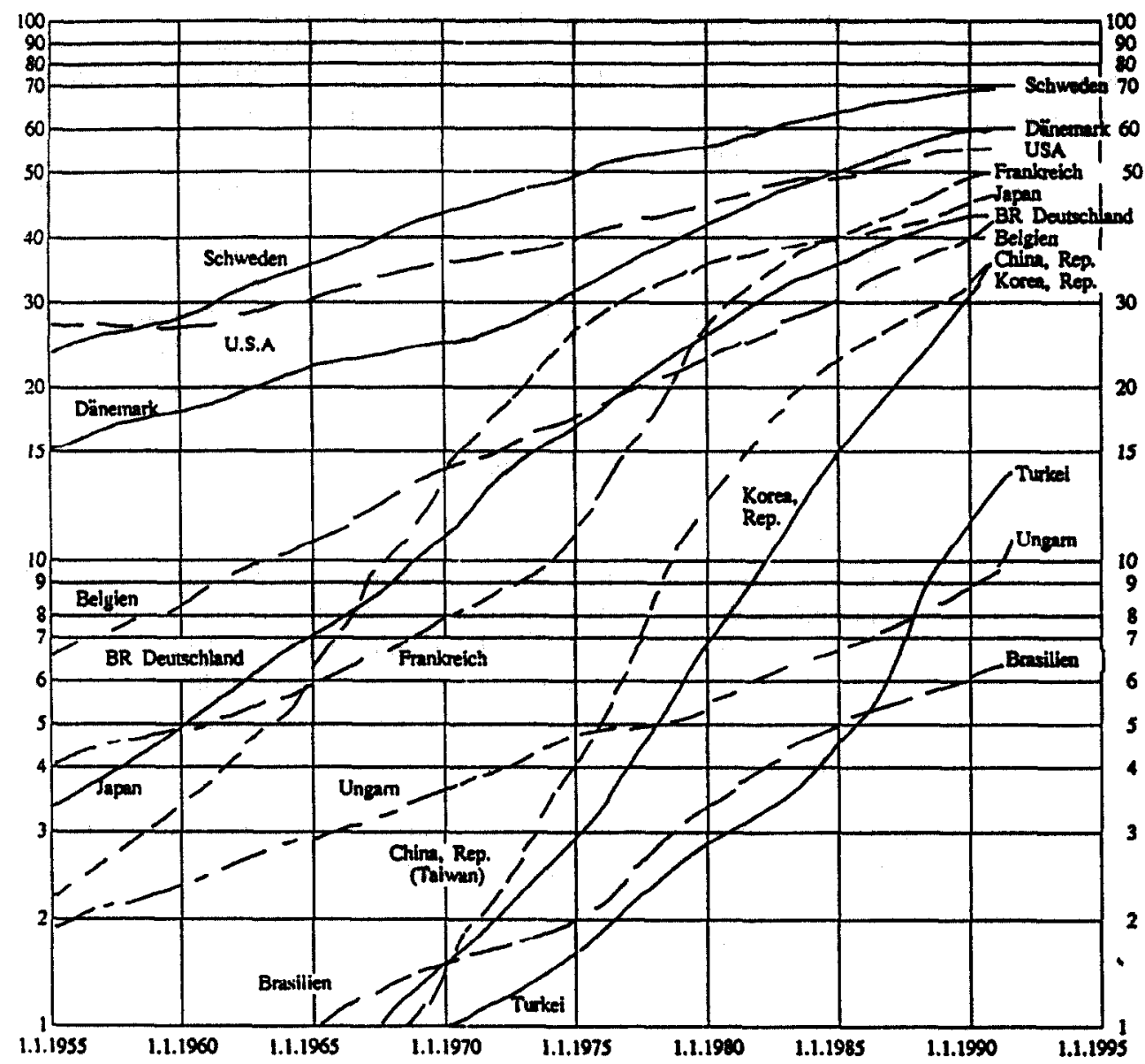

Graph: Main lines per 100 inhabitants

Some of the best long term growth performances (maesured from the graph) are:

$\begin{array}{ll}\text { Turkey (Turkei, 86-89) } & 28 \% \\ \text { France (Frankreich, 76-80) } & 19 \% \\ \text { Korea, Rep. } & 18 \% \\ \text { Japan } & 16 \%\end{array}$

International Telecom Statistics 1993, Siemens 1993, page 36.

<igure 1> Growth performances of World Telecommunications

KOREASAT itself in Korea, which has a high-density population of approximately $43,210,000$ within a land area of $99,000 \mathrm{~km}^{2}$ as well as a high teledensity of about $20,000,000$ lines. Apart from its economic aspect, yet, it has strategic meanings in terms of political, cultural and geographical reasons. For example, Korea has been divided into two (South and North) with different ideologies and surrounded by 
<Table 3> Evolution of the TDX-Se ries (1977-1991)

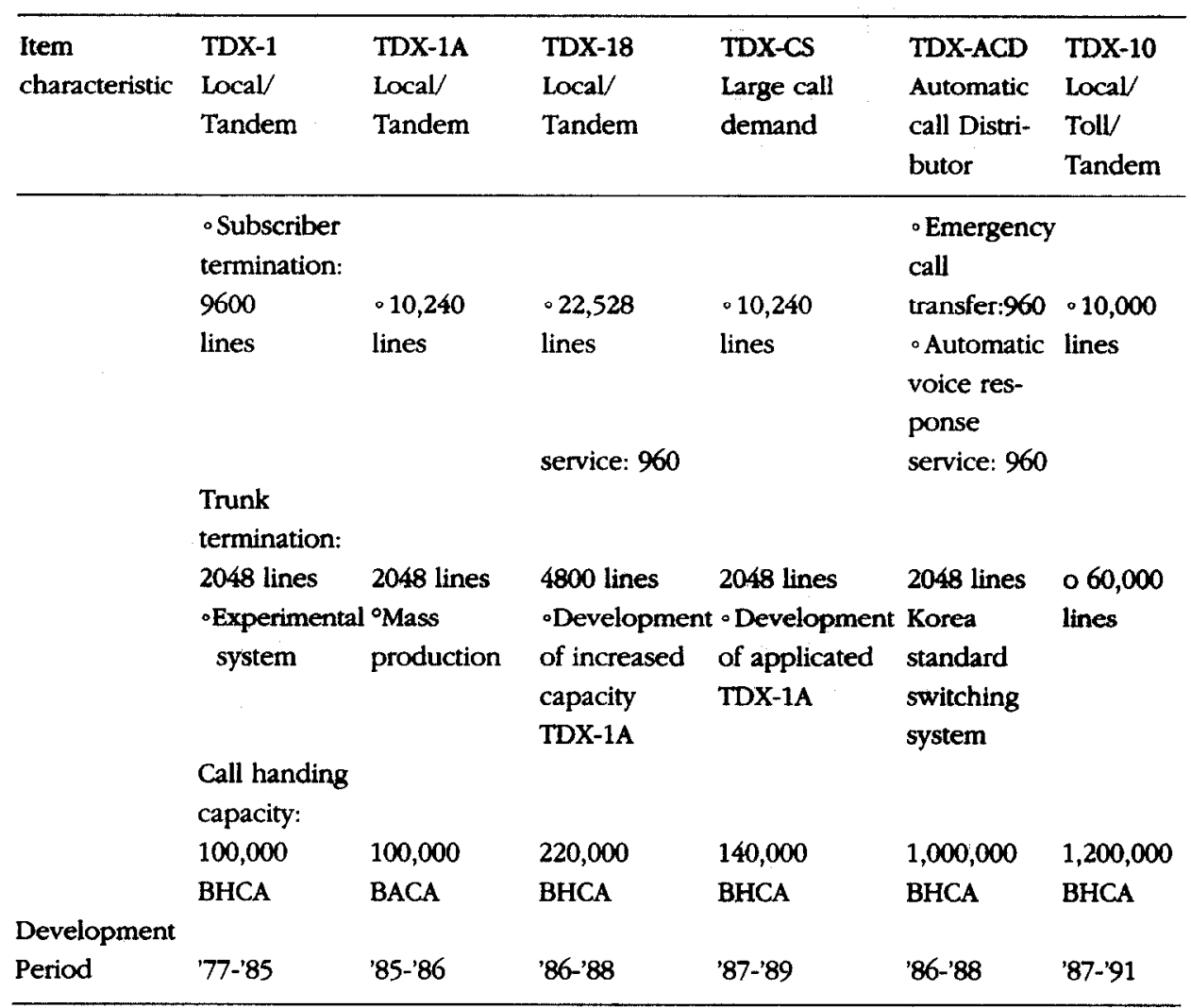

Source: McClelland, 1992, p.180.

powerful countries including the U.S.A., Japan, China, and Russia. Most of all, various satellite broadcasting services have been spilled over from Japan, Hong Kong, and others to Korean audiences for some times.

\section{Submarine Optical Fiber Cables}

On the basis of mid- and long-term plans, Korea also intends to construct more submarine optical fiber cables in the Asia-Pacific region for self-reliance from neighboring countries particularly Japan in order to link other regions or countries directly. In particular, development of optical fiber technologies accelerated to construct several submarine cable projects in the region, as seen in <Table $4>$

Another important cable project, which many countries are at present interested and involved in, will be the TSL linking Europe and Far-East Asia passing through the main land of Russia. There are at large two groups of countries which partici- 
<Table 4> Submarine Cable Projects in Asia-Pacific Region

\begin{tabular}{lllrl}
\hline Areas & Projects & Countries & \multicolumn{1}{c}{ Circuits } & \multicolumn{1}{l}{ Year } \\
\hline Asia & J-K & Korea-Japan & 1,200 & Nov 1980 \\
& H-J-K & Kor-Jap-Hong Kong & 3,360 & May 1990 \\
& GPT & Guam-Phil-Taiwan & 110 & Dec 1989 \\
& BMP & Bruni-Mal-Phil & 2 & Mar 1992 \\
& TPC3 & Jap-Guam-Haw-USA & 687 & Apr 1989 \\
& NPC & Jap-USA-Alaska & 180 & May 1991 \\
& APCN & Kor-Jap-Asians & 60,480 & $1995 / 96$ \\
& FLAG & UK-Kor-Jap & 120,960 & 1995 \\
& R-J-K & Kor-Jap-Russia & 15,120 & Jan 1995 \\
\hline Pacific & TASMAN2 & Aus-New Zeal & 15 & Mar 1992 \\
& TPC4 & Jap-USA-Can & 540 & Oct 1992 \\
& TAT9 & USA-UK-France & 60 & Mar 1992 \\
\hline Atlantic & TAT19 & USA-Ger-Netherlands & 30 & Aug 1992 \\
\hline
\end{tabular}

Note: Kor (Korea); Jap (Japan); Phil (Philipine); Mal (Malaysia); Haw (Hawaii); Aus (Australia); Can (Canada); Ger (Germany)

pate in the project: One is investors including Russia (Intertelecom), UK (C\&W), USA (US West), Italy (STET), and Denmark (TD \& GN); The other is users (or service providers) including USA (AT\&T \& MCD), UK (BT \& C\&W), Germany (DBP), Denmark (TD), Russia (Intertelecom), Korea (KT), and Japan (KDD) tentatively. According to the MOU singed in September 1992, it is scheduled to be completed by the first half of 1995 .

\section{Cable Television (CATV)}

Like many countries (E.J. Kim and Y.O. Jin, 1993c), Korea has also pursued to provide people with CATV services from January 1995. Because of its complex characteristics involved in broadcasting, information, and telecommunications, however, both the Ministry of Communications (MOC) and the Ministry of Information (MOI) have been involved in the project with different responsibilities: the MOC has a right to designate transmission network providers; whilst the MOI franchises CATV operators and program providers (MOC, 1993c).

In accordance with the CATV Law (1991) which allows more than two operators or providers for increasing managerial efficiency and competition with preventing them from monopolizing the business, the MOC designated two transmission operators (e.g., KT and Korean Electronic Power Corporation: KEPOC), and selected four others (e.g., DACOM and Goldstar affiliate) on December 301993. The four selected companies can be later designated, if they comply with the 
required conditions.

Regarding program providers, the MOI franchised 19 program providers on August 311993 according to 11 different types of services such as news, movies, sports, entertainment, education, music, children, women, religion, and transportation and travel. It is worth noting that many program providers have foreign joint ventures including CNN (USA), TRANSTEL (Germany), BBC Enterprise (UK), although foreign investments are limited to between $20 \%$ and $30 \%$ of the total equities of each provider.

The MOI also selected 50 CATV operators in a capital city and regional areas: 21 in Seoul, 7 in Pusan, 4 in Taeku, 5 in Incheon, 2 in Kwangju, 2 in Taejeon, 1 each in 9 other provinces. They shall be finally designated as operators, if they comply with the certain requirement. It, yet, implies that each operator monopolizes its services within the franchised area.

Prior to operating the commercial CATV services, KT has been under the trial to 10,000 households in Seoul through 14 channels from 1991. The technical types of transmitting the programs are in general using video tapes, microwaves, fiber optical cables, and satellites based on either analogue or digital method (H.J. Lee et. al., 1994.). In case of Korea, fiber optical cables will be used in connection with digital satellites (e.g., KOREASAT) later. However, unlike the UK or other countries, the cable system used to convey CATV services will not be able to carry telecommunications services so far in Korea.

In sum, the relations between government strategies and technology development - in particular, large scale and risk involved technology development - have been closely intertwined in Korea. Indeed, the series of TDX has been domestically developed by closer collaborations among the government (MOC), R\&D institute (ETRI), and the major manufacturing companies. Both the plans for satellite and fiber optical cable systems have been also pushed forward by the MOC, KT, and R\&D institutes in association with foreign partners.

\section{Variety of New Telecommunications Services}

The recent regulatory reforms above mentioned are mainly based on different categories of services. The liberalization has impacted upon not only the various kinds of telecommunications services, but also on the increases of their traffic volumes.

For example, international telephone traffic has seen a near $40 \%$ year-on-year growth over the past few years, which ranks Korea second behind only Japan (McClelland, 1992, p.179). Since the end of 1991, the ten largest countries with whom Korea exchanges international voice services are as follows: the U.S.A., Japan, Jong Kong, Germany, United Kingdom, Singapore, Canada, Australia, 
< Table $\$>$ Tentative Plan of Telecommunications Services

\begin{tabular}{|c|c|c|}
\hline $\begin{array}{l}\text { 1st Stage } \\
\text { (till 1991) }\end{array}$ & $\begin{array}{l}\text { 2nd Stage } \\
(1992-1996)\end{array}$ & $\begin{array}{l}\text { 3rd Stage } \\
(1997-2001)\end{array}$ \\
\hline Telemetering service & Basic VAN service & Supur DB service \\
\hline TELEPIA & Large public-use DB & Teleport \\
\hline $\mathrm{CDA}$ & Telemonitoring service & Teleworking \\
\hline Learning information service & Videotex & Working-home service \\
\hline E-mail service & EDI & \\
\hline CSDN & Telewriting & \\
\hline \multicolumn{3}{|l|}{ 700-Service } \\
\hline & Group-so-space data servie & \\
\hline \multirow{6}{*}{$\begin{array}{l}\text { Teleconferencing service } \\
\text { CATV demonstration service }\end{array}$} & PC-MHS & \\
\hline & & \\
\hline & PSDN & \\
\hline & Visual answering service & \\
\hline & CATV service & \\
\hline & Remote Medical Service & \\
\hline
\end{tabular}

Source: McClelland, 1992, p.179.

France, and Taiwan.

In particular, VAN services including various database, E-mail, and teleconference became lucrative and futuristic businesses, in which not only the existing big service providers and conglomerates but also small and middle-sized companies can participate. It is thus of significance that many new jobs are expected to be created in this service. The overall markets for telecommunications services increased in general, and the VAN service markets are expected to further grow as seen in <Table $5>$.

\section{Balancing Telecommunications Tarifis}

Tariff is one of the key factors which has contributed to the development of telecommunications and it has been sensitive to the influence of the liberalization in Korea. That is, one mechanism through which the government raised capital in order to develop the basic telecommunications facilities was the increase of tariffs in the early 1980 s.

The telecommunications tariff in Korea is largely collected from three different categories: 1). local calls; 2). long-distance calls within the country; and 3). international calls. Each category of calls are again divided into two categories: subscribers' phones and public pay phones. As a way of raising investments required for developing the basic telecommunications facilities, the MOC increased the tar- 
iff by $20 \%$ on long-distance calls and by $33 \%$ on subscribers' phones for the local calls in December 1981. In fact, the international increase of tariff by the government was the first and the last so far.

Since KT separated its operations and budgets from the MOC in 1982, the tariffs of long-distance calls have continued to decrease to $17 \%$ in $1986,20.8 \%$ in 1988 , $10 \%$ in 1990 , and $7.4 \%$ in 1991 . Furthermore, owing to the development of basic telecommunications facilities and competition, KT began to introduce several pricing services by discounting the tariff in the 1980s. In 1991, competition between KT and DACOM over international calls also brought about further discount of the tariff. In 1994, particularly, there was balancing telecommunications tariff such as reducing the tariff for international and long-distance calls while increasing that for local calls to meet the further restructuring of telecommunications service sectors in accordance to the advent of World Trade Organization (WTO).

\section{Expansion of Cooperative Relations at Both Bi-Lateral and Multi-Lateral Levels}

Inasmuch as the world politico-economic environment is ever changing and telecommunications is connecting the rapidly changing world in a much closer and quicker manner, so Korea has been strengthening her cooperative activities at both bi-lateral and multi-lateral levels.

Regarding the bi-lateral cooperation in the telecommunications sector, it ranges from the government level to private ones. For instance, the Korean Government (i.e., MOC) has actively exchanged information and personnel, signed the Memoranda of Understanding (MOU), and formed various cooperative committees with her counterparts from various countries including the former socialist countries, with which she had little opportunities for exchanges of any kind due to politico-ideological reasons. As for the industrial levels, both common carriers and private companies have also carried out cooperative activities or entered into foreign markets.

In the light of multi-lateral cooperation, all the relevant entities centered by the MOC have participated in various types of multi-lateral cooperation through regional and international organizations. As a member, for example, Korea has actively attended and involved in the activities organized by the ITU, the International Telecommunications Satellite Organization (INTELSAT), the International Maritime Satellite Organization (INMARSAT), the former General Agreement on Tariffs and Trade (GATT) replaced by the WTO, the Asia-Pacific Telecommunity (APT), the Asia-Pacific Economic Cooperation Council (APEC), the United Nations Economic and Social Commission for Asia and the Pacific (ESCAP) and so on. To examine the possibility of joining the Organization for Economic 
Cooperation and Development (OECD) in the mid-1990s, moreover, the government now exchanges information with the OECD itself and participates in its various Committees.

\section{Facing Various Internal and External Challenges}

One of the effects from changing policies such as liberalization is the trade unions' movement in the field of telecommunications. The role of trade unions is basically to promote better living conditions of workers or staff. Although their bargaining power had been rather weaker in Korea until the late 1970s (Park, 1998, p.110) and even until the early 1990s, the trade unions-at least, the KT's-began to raise their voices criticizing the government policies, demanding the increase of salaries, upgrading their quality of life and working conditions, and so forth.

In addition, the internal changes such as the blurred service areas and diversified actors with intensed competitions at various levels as well as the external forces such as the Uruguay Round leading to further opening service markets (e. g., local voice services) have been incessantly challenging various aspects of telecommunications within Korea's unique politico-economic regime. Thus, the MOC in association with various actors has been under the review on large scale restructuring of the current distinction among services or service providers (E.J. KiM, 1994).

Leaping towards the information society in the 21 st century, overall, a variety of policies and strategies should be established and implemented in various areas. As a result, various new and high quality of services with low costs need to be further developed and provided; small and medium sized businesses to be promoted; and various actors including the private sectors with capabilities of manpower and capitals to enter into foreign markets and participate in regional and international organizations through which they can extend cooperative relations and expand joint-ventures with their counterparts.

\section{vi. Conclusion}

Each type of models has its own strength and weakness. Moreover, there can be further detailed types of models which better describe certain cases of countries depending on their unigue conditions. Nonetheless, it is clear that the mobile of liberalization with competitions could be a tool for stimulating the development of telecommunications. Most of all, the liberalizations per se can neither guarantee efficient management nor provide customers with low costs and a high quality of services-i.e., telecommunications welfare. 
It must be adapted to a specific social, economic and political environment. Government intervention that introduces a form of liberalization appropriate to the country concerned can be more efficient and feasible than full-scale liberalization based on free-market principles in order to achieve development and improvement in telecommunications.

However, the government-driven liberalization can face more and more challenges in the forthcoming era of the new World Trade Organization (WTO). Thus, last but the least, the author suggests some directions for telecommunications development to countries like Korea as follows among many others:

1) Government-arbitrated rather than government-intervened policies-i.e., small and efficient government with less bureaucracy-will be more effective to meet or mediate various, if not conflicting, interests of the actors;

2) Market-oriented policies will be recommendable not only to meet the demands for various users but also to encourage the private sectors to exert their creativities and capital capabilities;

3) Technological strategies to develop both environment and user friendly facilities, balance between hardware and software markets, achieve self-reliance, and to meet the forthcoming Techno Round or Environment Round;

4) Extended scope of activities including the political dialogue and standardization through the global arena such as the WTO, ITU, OECD, APEC and others will be more and more inevitable in the 21 st century.

\section{Notes}

1) The term 'bureaucratic authoritarianism' as applied to Korea, especially in the 1960 s and 1970s, is derived from the views that its policy was bureaucratic in as much as it was governed by military rulers rather than the personal rule of a military strongman, whilst it was authoritarian because obedience to government was required of the entities concerned. See E.J. Kim, 'Dynamic interlinkages between the R.O. Korea and the ITU through evolving issue-structure', Ph.D. thesis, City University, London, 1990, p.6; and P.W.Kuznets 'Government and economic strategy in contemporary South Korea', Pacific Affairs, Vol 58, No 1, 1985, p. 49.

2) In this article the term 'corporatism' implies a system in which the government plays a central or intermediary role among all the interest groups such as various infrastructures, whilst the trem 'pluralism' implies a system that has several centres of power among various interest groups ratehr than one in which the government is the sole controller of them. See D. Robertson, Modern Politics, Europa, London, 1985, pp. 71 and 258-259; and R.M. Martin, 'Pluralism and the new corporatism', Political Studies, Vol XXX1, 1983, pp. 86-102. 


\section{References}

Arnold, E. and K. Guy. 1986. Parallel Convergence: National Strategies in Information Technology, Frances Pinter, London.

Choi, B.I. 1991. Policy Reform of the Korean Telecommunications Market. A paper presented at the Third Korea-U.S. Telecommunications Private Sector Consultation. Washington, D.C.

Dholakia,R. \& Harlam, R., (1994), "Telecommunications and economic development: Econometric analysis of the US experience", Telecommunications Policy, Vol.18, No.6, pp. 470-477, London.

Drake, W.J., (1988), "WATTC-88: Restructuring the International Telecommunication Regulations", Telecommunications Policy, Vol. 12, No.3, pp. 217-233, London.

Garfinkel, L., (1994), "The transition to competition in telecommunication services", Telecommunications Policy, Vol 18, No.6, pp.427-431, London.

GATT, (1988), "Trade Policy", Focus: GATT Newsletter, No.5, Geneva.

Haggard, S. et.al. 1987. "Theories of International Regimes," International Organization, Vol.41, No.3, pp. 491-517

Hills, J., (1989), "Telecommunication policy: the movement towards liberalization and privatization-Japan and Australia compared", Telecommunication Journal, Vol.56, No.3, pp.163-171, Geneva.

Hwangbo,H. 1992. Mugunghwa: The First Korean Domestic Satellite or FSS \& DBS Services. A paper presented at the 1992 United Nations Workshop on Space Communication for Development, 24-27 November, Seoul.

ITU, (1959), Telecommunication Journal, Vol. 26, No. 8, p. 171. Geneva.

ITU, (1992), The Final Act of the Additional Plenipotentiary Conference, Geneva.

ITU, (1994), World Telecommunication Development Report, Geneva.

Jeonjasibosa, 1992. Annual Report of Telecommunications, Seoul.

Kim,E.J., (1990), Dynamic Interlinkage between the R.O.Korea and the ITU through Evolving Telecommunications Issue-Structures, Ph.D.Thesis, The City University, London.

Kim, E.J. (1992), "Changing Telecommunication policies and Infrastructure in the R.O. Korea", Telecommunication Journal, Vol. 59, No. 12, pp. 173-387, Geneva.

Kim, E.J., (1993a), "Telecommunications Development in the Republic of Korea", Telecommunications Policy, Vol. 17, No. 3, pp. 118-138, London.

Kim,E.J., (1993b), Analysis of Implementation of the Revised Basic Legal Instrument of the ITU, KISDI, Seoul.

Kim,E.J. and Y.O.Jin, (1993c), "The Evolution of Telecommunications Policy in the Republic of Korea", International Review of Comparative Public Policy, Vol. 5, pp. 231-256, Greenwich Connectricut.

Kim,E.J., (1994), “Politico-Economic Impact on Evolution of Information \& Telecommunications in the Republic of Korea", A paper presented at the LAMCR, Seoul.

Korea Gevernment, (1993), The New 5-Year Economic Development Plan, Seoul.

Kuznets, P.W. 1985. "Government and Economic Strategy in Contemporary in South Korea" Pacific Affairs, Vol. 58, No. 1, pp. 44-66. 
Lee, H.J. et.al., (1994), "Analysis of Economy for CATV Program Transmission", Telecommunication Review, Vol. 4, No. 1, pp. 42-61, Seoul.

Longley, D. \& Shain, M., (1989), MacMillan Dictionary of Information Tecbnology (3rd, ed.), MacMillan Reference Books, London.

McClelland, S. 1991, "South Korea: Communication Structure,", Telecommunications, Vol. 25, No.10, pp.179-180.

Ministry of Communications, Korea, (1991), Annual Report, Seoul.

Ministry of Communications, Korea, (1993), White Paper, Seoul

Ministry of Trade, Industry, and Energy, Korea, (1992), Newsletter, Seoul.

Ministry of Justice, Korea, (1994), Basic Documents Supplement to Uruguay Round, Seoul.

Park, S.I. 1988, "Labor Issues in Korea's Future." World Development, Vol.16, No.1, p.110.

Scibberras,E. \& Payne,B.D., (1986), Telecommunications Industry: Tecbnical change $\mathcal{E}$ international competitiveness, Longman, London.

Seo, B.H. et.al. 1991. Service Systems and Business Strategy in the Satellite Communications Industry, KISDI, Seoul 